\title{
BLNK Gene
}

National Cancer Institute

\section{Source}

National Cancer Institute. BLNK Gene. NCI Thesaurus. Code C26635.

This gene plays a role in signal transduction and B-cell development. 